\title{
Modification of Animal Drawn Drum Type Seed cum Fertilizer Applicator for Direct Seeded Rice
}

\author{
Animesh Chandravanshi*, S.V. Jogdand, Aditya Sirmour and Ashwani Korram
}

Department of Farm Machinery and Power Engineering, IGKV, Raipur, India

*Corresponding author

\begin{tabular}{|l|}
\hline Key w or d s \\
$\begin{array}{l}\text { Seed cum fertilizer } \\
\text { applicator, rice, } \\
\text { field capacity, field } \\
\text { efficiency }\end{array}$ \\
\hline Article Info \\
\hline $\begin{array}{l}\text { Accepted: } \\
\text { 14 December } 2017 \\
\text { Available Online: } \\
\text { 10 January } 2018\end{array}$ \\
\hline
\end{tabular}

\section{Introduction}

Chhattisgarh, the $26^{\text {th }}$ state of Indian Union came in existence on 1 November 2000, is popularly known as "rice bowl of India" because maximum area is under rice cultivation during kharif and contribute major share in national rice production. The total geographical area of the state is around 13.79 million ha of which cultivable land area is

\begin{abstract}
A B S T R A C T
The present study was aimed to modify the existing animal drawn drum type seed cum fertilizer applicator. A seed cum fertilizer applicator was developed at FAE, IGKV, Raipur in the past years for the sowing operation of paddy in rows and it also maintain plant to plant distance along with fertilizer application, but some problems were observed during the operation of this machine. Dropping of seed and fertilizer from the drums encountered the problem of gathering of seeds in the chute. The seeds sown were left uncovered resulting in losses due to birds. Considering the above facts and studies, an attempt was made to modify the machine to overcome the problems, for that front half of the parabolic channel was made straight and placed at an angle of $35^{\circ}$ and a covering device is developed to prevent dropped seeds from birds as well as the machine was tested in laboratory and field. In laboratory testing seed rate and fertilizer rate was found as 18.39 $\mathrm{kg} / \mathrm{ha}$ and $41.45 \mathrm{~kg} / \mathrm{ha}$ respectively, During the field test the draft, operational speed, power requirement, seed rate and depth of seed placement were recorded as $456.36 \mathrm{~N}, 2.36$ $\mathrm{kmph}, 0.30 \mathrm{~kW}, 19.64 \mathrm{~kg} / \mathrm{ha}$ and $4.72 \mathrm{~cm}$ respectively. The effective field capacity and field efficiency of the machine was found $0.151 \mathrm{ha} / \mathrm{h}$ and $63.98 \%$.The energy consumption and cost of operation was found $89.2 \mathrm{MJ} / \mathrm{ha}$ and $578 \mathrm{Rs} / \mathrm{ha}$. On the basis of the findings all over performance of the developed drum type seed cum fertilizer applicator was found better as compared to Indira seed drill and sowing behind the plough and the performance of the machine was found as per desirable.
\end{abstract}


technology that would increase profit and ensure sustainable rice production. The method of rice seeding varies from region to region and also depends upon weather condition prevailing at the time of sowing. There are two common methods of rice seeding prevail in our country i.e. broadcasting and transplanting. Transplanting is labor intensive and expensive can be replaced by direct seeding that can reduce the labor needs by $20 \%$ and would significantly decrease costs of rice production (Chandrasekhararao et al., 2013) Line sowing could be a good alternative of biasi in case of low rainfall during first spell monsoon and in upland paddy fields. Therefore a low cost seed cum fertilizer applicator could be a best option to perform the line sowing. The existing 8 row drum seeder is used to sow seeds only. A seed cum fertilizer applicator was developed at FAE, IGKV, Raipur in the past years but some problems were observed during the operation of this machine. The seeds were accumulated in the chute during the sowing and also the seeds sown were left uncovered resulting in losses due to birds. Considering the above facts and studies an attempt was made to modify the machine to overcome the problems, for that front half of the parabolic channel was made straight and placed at an angle of $35^{\circ}$ and a covering device is developed to prevent dropped seeds from birds, resulting dropping of seeds in furrows with satisfactory seed placement at desired spacing with covering by soil.

\section{Materials and Methods}

Modification of the drum seeder was done in the laboratory of SVCAET, FAE, IGKV, Raipur with standard procedure.

\section{Development of channel}

Channel is made up of $20^{\times} 5 \mathrm{~mm}$ M.S. flate and G.I. sheet of 16 gauge thickness. The width of channel is kept $60 \mathrm{~mm}$ so that when the seed and fertilizer drops they directly fall on the channel and not fall on the ground due to vibration or other shocks during the field operation. Channel is welded on the lower portion of the frame. A M.S. square pipe of $30^{\times} 30 \mathrm{~mm}$ was welded on the lowest point of the channel from where the mixture of seeds and fertilizer drops down to the ground.

The shape of the channel made by previous researcher was parabolic due to which there was accumulation of the seeds occur at the outlet, and dropping of seeds encountered problem to overcome that front half of the parabolic channel was made straight and placed at an angle of $35^{\circ}$ which matches with the angle of repose of paddy and remaining half portion was kept parabolic which is shown in Fig1

\section{Development of covering device}

Covering device is developed to prevent dropped seeds from birds a M.S. pipe of $900 \mathrm{~mm}$ length and $2.7 \mathrm{~kg}$ weight with $70 \mathrm{~mm}$ outer diameter was used to serve the pupose of covering the dropped seeds in furrows.

The pipe was atteached to the back portion of the frame with the help of bush. An adjustment was provided to lower or upper the covering device. All that fabrication was done in the research workshop of Swami Vivekanand College of Agricultural Engineering and Technology, Faculty of Agricultural Engineering, IGKV, Raipur by standard manufacturing processes. The clear view of the device is shown in the Fig2

\section{Details of field experiment}

Test Crop: Rice (Oryza sativa L.)

Variety: IGKV - R1

Season: Kharif

Date of sowing: 16-06-2017 
Method of sowing:

T1: Animal Drawn Drum Seeder

T2: Indira Seed Drill

T3: Manual line sowing behind the Plough

Replications: Five

Design of experiment: Random Block Design (RBD)

The following parameters were taken during the field test:

Speed

Power

Field Capacity

No. of plants $/ \mathrm{m}^{2}$

Depth of placement of seed

\section{Operating Speed}

The speed of operation was measured by recording the time required to cover $20 \mathrm{~m}$ distance in the field during operation.

Speed $(\mathrm{km} / \mathrm{hr})=3.6 \mathrm{x}$ distance traveled $(\mathrm{m}) /$ time (s)

\section{Power Requirement}

The power requirement was determined from draft and speed using the relation

Power $(\mathrm{hp})=$ Draft $\times$ speed $/ 75$
Where, Draft in kgf; and Speed in m/s.

\section{Field Capacity}

Theoretical field capacity was calculated by following formula

$\mathrm{TFC}(\mathrm{ha} / \mathrm{h})=(\mathrm{W} \times \mathrm{S}) / 10$

Where, $\mathrm{S}=$ Speed of operation, $\mathrm{km} / \mathrm{h} ; \mathrm{W}=$ Theoretical width covered, $\mathrm{m}$; and $\mathrm{W}=$ No. of furrow openers multiplied by distance between two consecutive furrow openers, $\mathrm{m}$.

No. of Plants $/ \mathrm{m}^{2}$

Number of plants per square meter was counted from each of the five randomly selected one meter quadrates after the 25 DAS (Days after Sowing).

\section{Depth and Placement of Seed and Fertilizers in Row}

The seeder was operated in the field under normal seedbed conditions. A distance of 20 $m$ length was covered and the soil was removed carefully without disturbing the seeds and fertilizers.

Then the depth and placement of seeds and fertilizer were measured.

Table.1 Field condition during the test

\begin{tabular}{|l|l|l|}
\hline S.No & perticulars & situation \\
\hline $\mathbf{1}$ & Farming situation & Dry Seeding \\
\hline $\mathbf{2}$ & Location & SVCAET Testing plot \\
\hline $\mathbf{3}$ & Type of Soil & Sandy Loam \\
\hline $\mathbf{4}$ & Moisture content of soil & $16.05 \% \mathrm{db}$ and $13.73 \% \mathrm{wb}$ \\
\hline $\mathbf{5}$ & Bulk density of soil & $1.65 \mathrm{~g} / \mathrm{cc}$ \\
\hline 6 & Area taken for field performance & $1034 \mathrm{sqm} .(0.1034 \mathrm{ha})$ \\
\hline 7 & Field prepration & $\begin{array}{l}\text { Indigenous plough and rotavator } \\
\text { (animal drawn) }\end{array}$ \\
\hline
\end{tabular}


Table.2 Findings of field performance of different treatments

\begin{tabular}{|l|c|c|c|}
\hline \multicolumn{1}{|c|}{ Parameters } & \multicolumn{3}{|c|}{ Data of field performance } \\
\hline & $\begin{array}{c}\text { Drum } \\
\text { seeder(T1) }\end{array}$ & $\begin{array}{c}\text { Indira seed } \\
\text { drill(T2) }\end{array}$ & $\begin{array}{c}\text { Sowing behind } \\
\text { the plough(T3) }\end{array}$ \\
\hline Draft(N) & 456.36 & 490.89 & 586.34 \\
\hline Travelling speed, $\mathrm{km} \mathrm{h}^{-1}$. & 2.36 & 2.34 & 1.50 \\
\hline Theoretical field capacity, $\mathrm{ha} \mathrm{h}^{-1}$. & 0.236 & 0.176 & 0.027 \\
\hline Effective field capacity, $\mathrm{ha} \mathrm{h}^{-1}$. & 0.151 & 0.110 & 0.016 \\
\hline Field efficiency, \% & 63.98 & 62.5 & 59.25 \\
\hline
\end{tabular}

Fig.1 Auto - CAD design view of channel and tyne

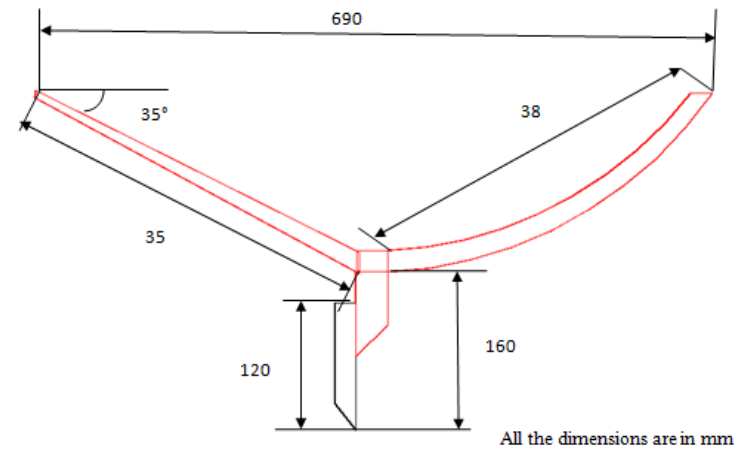

Fig.2 Auto - CAD design view of covering device
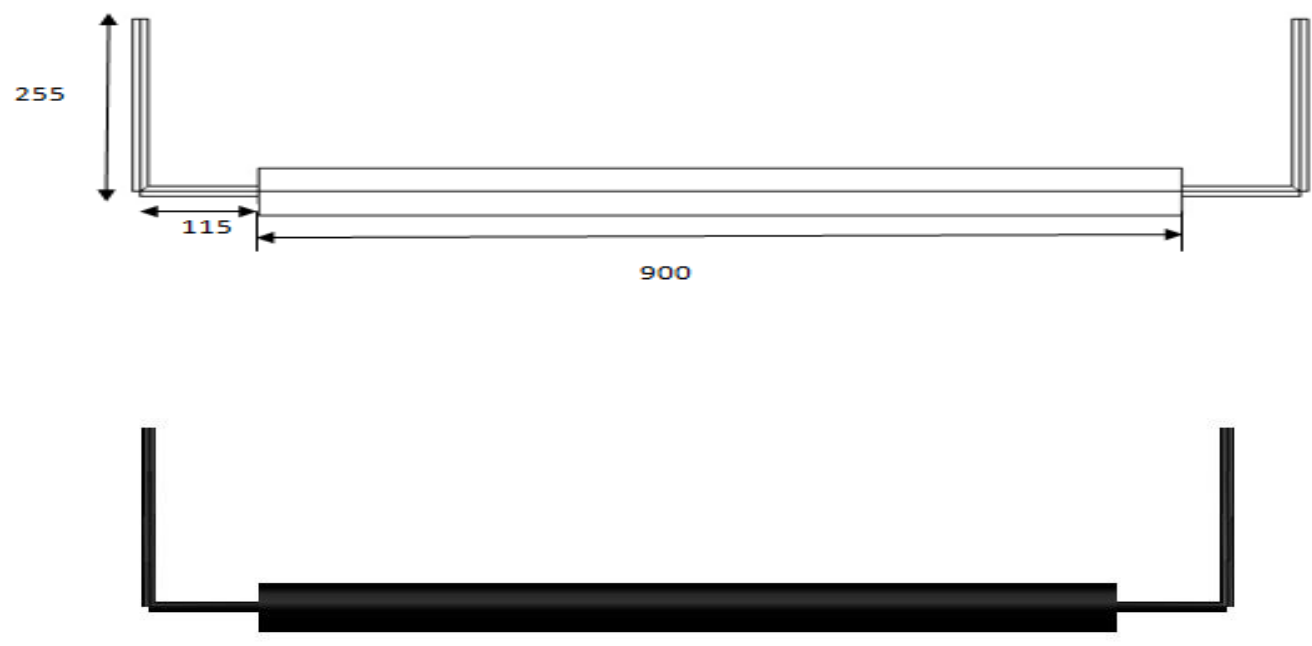
Fig.3 Front and side view of the seed cum fertilizer applicator
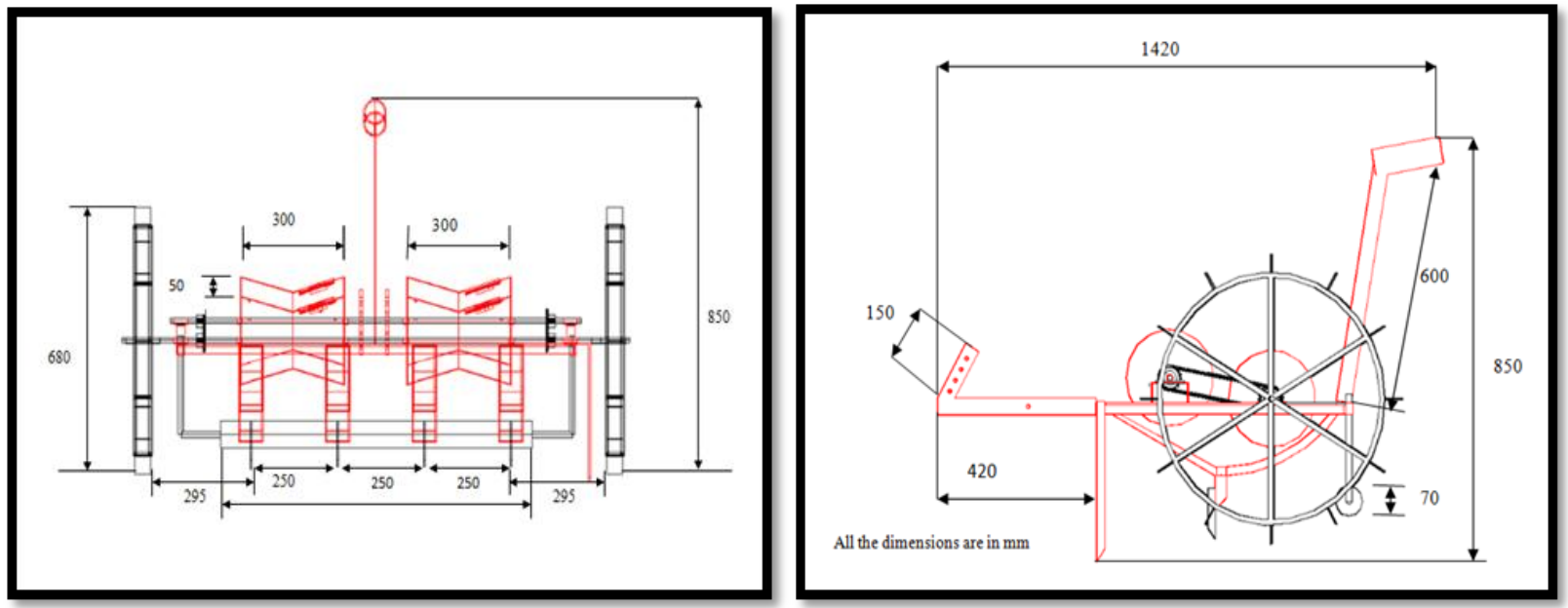

Fig.4 3-D Solid projection of the seed cum fertilizer applicator
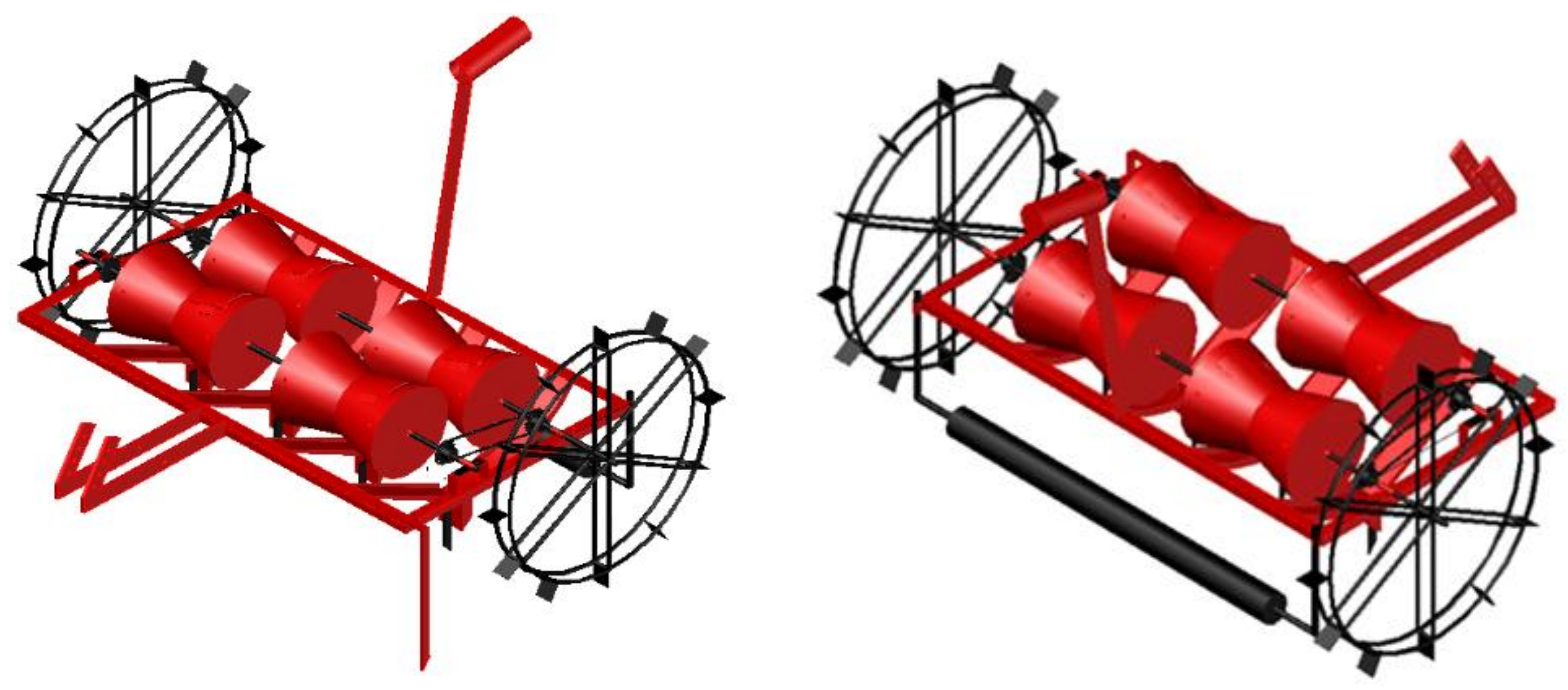

Fig.5 Layout of experimental plot
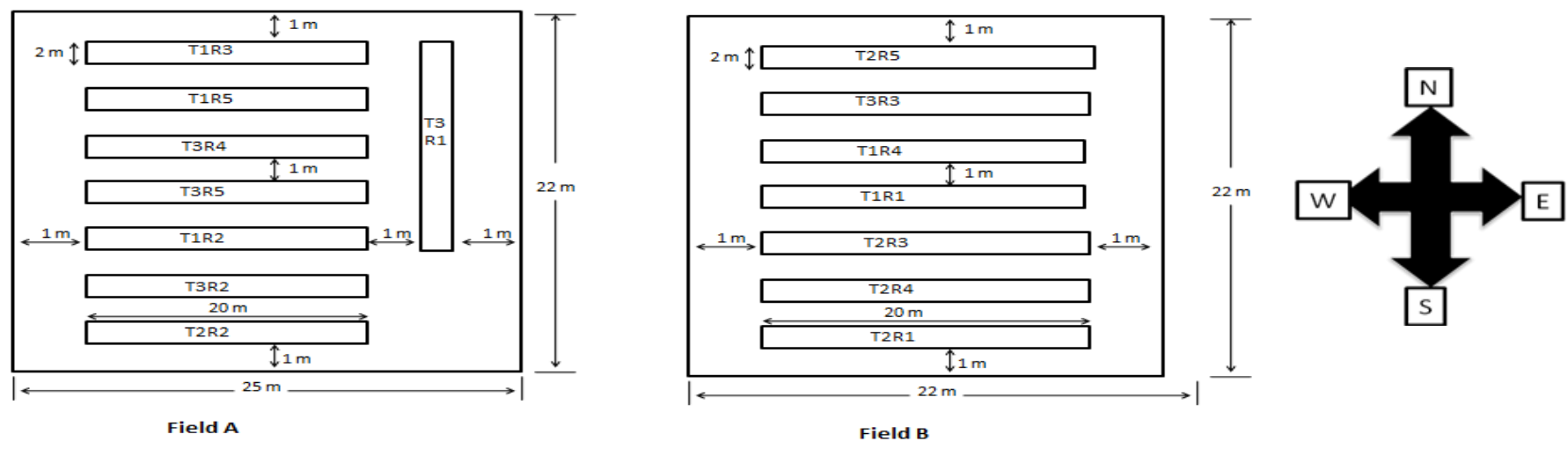
Fig.6 During the field test

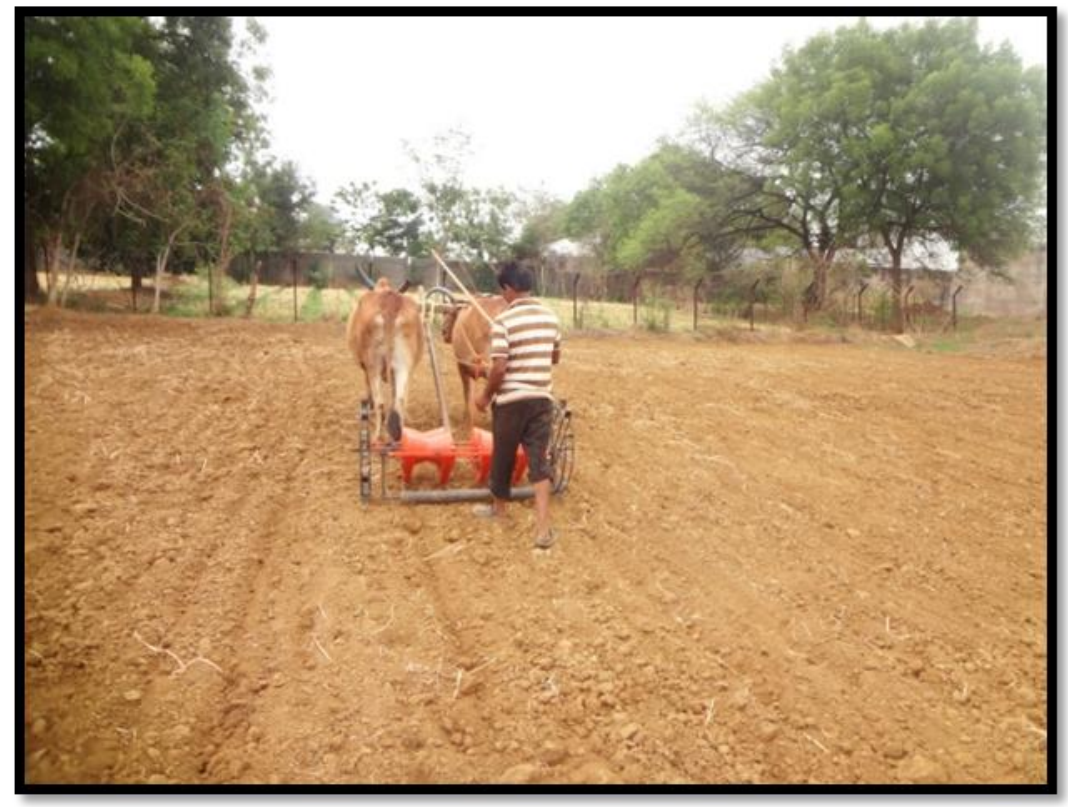

Fig.7 Number of plant per meter square

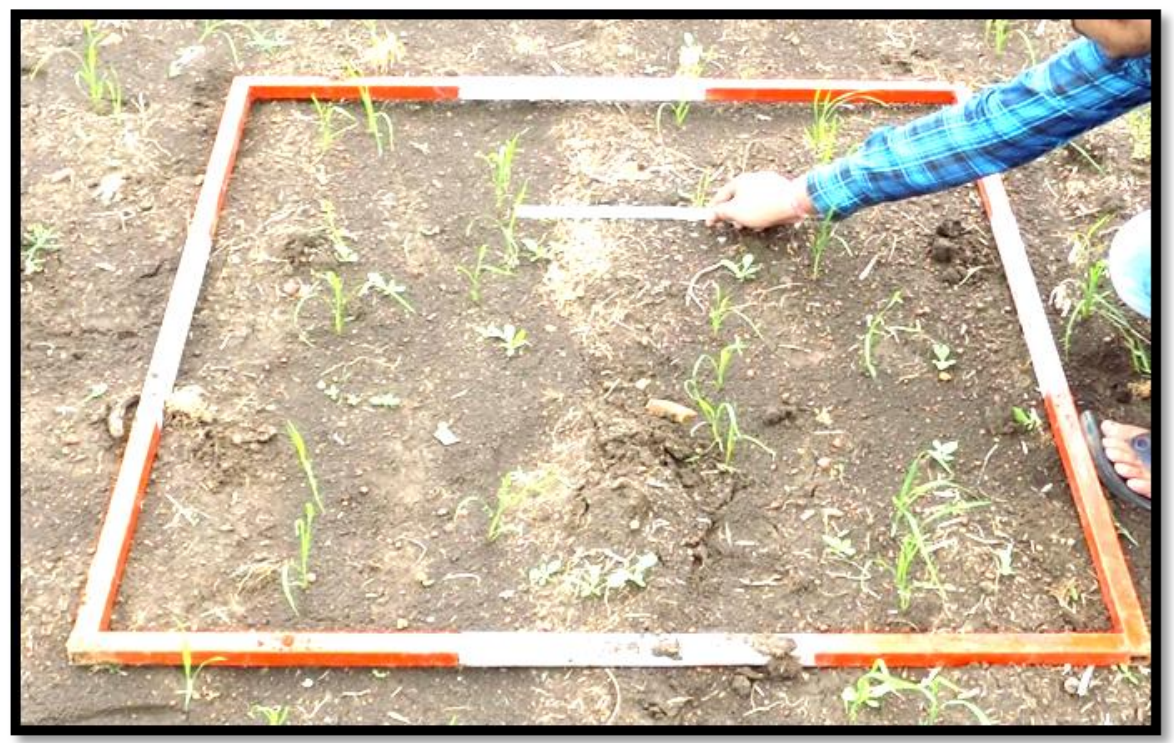

\section{Results and Discussion}

There are three treatments was taken during the sowing of paddy i.e. animal drawn drum type seed cum fertilizer applicator (T1), Indira seed drill (T2) and sowing behind the plough (T3). The field condition during the test was given in table 1 and the field performance of the respective machine is given in table 2. Depth of placement of seed and fertilizer of animal drawn drum type seed cum fertilizer applicator, and Indira seed drill was 4.72, and $3.52 \mathrm{~cm}$ were depth of placement of seed was highest in case of indigenous plough i.e. $10.34 \mathrm{~cm}$. In case of animal drawn drum type seed cum fertilizer applicator the seed rate 
was found $19.64 \mathrm{~kg} / \mathrm{ha}$. The energy consumption and cost of operation was found 89.2 $\mathrm{MJ} / \mathrm{h}$ and $578 \mathrm{Rs} / \mathrm{ha}$ respectively. Were the average plant population per square meter was 23 .

On the basis of the findings overall performance of the drum type seed cum fertilizer applicator was found better as compared to Indira seed drill and sowing behind the plough and the cost of the machine is within the buying capacity of the small and marginal farmers. Modification made in the seed cum fertilizer applicator resulted proper dropping of seeds in furrows with satisfactory seed placement with covering by soil.

\section{Acknowledgement}

The first author is thankful to Swami Vivekanand College of Agricultural Engineering and Technology, Faculty of Agricultural Engineering, IGKV, Raipur (CG), for providing financial assistance and technical support to conduct the experiment.

\section{References}

Anonymous 2015. Department of Agriculture C.G.

Anonymous. 2013. Annual Report of AICRP on Utilization of Animal Energy. Faculty of Agricultural Engineering,
IGKV Raipur (C.G).

Chandrasekhararao $\mathrm{C}$; S. Jitendranath and T.G.K. Murthy, "Resource optimisation in rice through direct seeding by drum Seeder." International Journal of Agriculture and Food Science Technology. 4(3), 239-246, 2013.

Chavan, S. P. and Palkar, S. M. 2010. Performance evaluations of paddy drum seeder. International Journal of Agricultural Engineering, 3 (2), 279287.

Islam Md. Syedul and Desa Ahmad 1999. Modification, test and evaluation of manually operated drum type seeder for low land paddy. Pertanika J. Science and Technology. 7(2) 85-98.

Kepner, R. A. Bainer Roy and Barger E. L., 1972. Principles of farm machinery 2 nd ed. xi, 486 p.: illus. ; 24 cm. Westport, Conn. : Avi Pub. Co., 1972.

Mahilong, K. 2015. Design and development of animal drawn seedcum fertilizer applicator for direct seeded rice. Unpublished M.tech. thesis Department of farm machinery and power engineering. FAE, IGKV Raipur.

Singh R.D., Singh Bhagwan and Singh K.N. 1983. Evaluation of IRRI-Pantnagar Bullock-Drown Six-Row paddy seeder. Agriculture mechanization in Asia, Africa and Latin America 14(3), 15-20.

\section{How to cite this article:}

Animesh Chandravanshi, S.V. Jogdand, Aditya Sirmour and Ashwani Korram. 2018. Modification of Animal Drawn Drum Type Seed cum Fertilizer Applicator for Direct Seeded Rice. Int.J.Curr.Microbiol.App.Sci. 7(01): 766-772.

doi: https://doi.org/10.20546/ijcmas.2018.701.093 